\title{
INTEGRATING SPATIAL PLANNING SYSTEMS IN THE FORMING OF REGIONAL POLICY IN CERTAIN COUNTRIES OF THE EUROPEAN UNION
}

DOI: http://dx.doi.org/10.18509/GBP.2019.63

UDC: 711.2-043.86(4-672EУ:497.2)

\author{
Metodi Ivanov ${ }^{1}$ \\ ${ }^{1}$ Sofia University „St. Kliment Ohridski“, Faculty of Geology and Geography, \\ Department "Regional Development", Sofia, Bulgaria
}

\begin{abstract}
The European Union's spatial development policy requires the implementation of targeted actions for its implementation. Spatial planning is often perceived as a set of methods used by the public sector to enable rational use of the land in the region, efficiency gains in environmental protection and improvement of economic and social development of the region. This is what makes it necessary to bring sectoral regional policies into support for the territorial cohesion policy of the regions at the member states of the European Union. The aim of the report is to present the modern spatial planning systems based on proactive mechanisms as well as to identify the applied spatial planning tools in some EU Member States with the capabilities of other economic instruments. This process defines an analysis of the links and coordination between the sectors in the regions and the related regional and sectoral policies resulting from the provision of different types of infrastructure in the regions, which is needed both for the population and development of the business. The contribution of spatial planning to the socio-economic development of the regions is indisputable but needs to be presented in order to create opportunities for overcoming regional imbalances in the Member States of the European Union.
\end{abstract}

Keywords: spatial planning, regional development, regional economy, regional planning

\section{INTRODUCTION}

The applied spatial development systems in the European Union follow established practices, traditions that are the result of socio-economic and political characteristics and, on the other hand, are also the result of differences in the cultural specificities of individual Member States, which is why the planned approach is a major in the development of a common European development policy. This calls for the necessary degree of cohesion and for the development of spatial planning systems in the countries of the European Union. The presentation of spatial planning requires a review of European legislation and its reflection in relevant strategic and regulatory documents. Spatial planning is often perceived as activities related to the physical placement of buildings and facilities, the construction of the adjacent infrastructure, the design and implementation of landscaping projects and other activities related to the development of the territory. However, spatial planning should not be considered as an application of territorial policy development but rather as a method of influencing the future design and localization of different types of activities in a spatial aspect. On the one hand, spatial planning should be considered at the same time as a method and approach for realization of strategic decisions in different directions in the socio-economic development of the territory of the country. At European level, four spatial planning approaches are basically 
observed, with the first approach being based on economic development, which is also the result of regional economic planning. In the second approach, integrated spatial planning is used as a way of planning the future development of the territory. The third approach is based on spatial planning directed to governance and the creation of opportunities for the full use of the earth in order to preserve it for future generations. And the fourth approach is related to urban lifestyle, town planning and urban development control. [1] Modern spatial planning is characterized by the existence of systematics as it is necessary to build the necessary mechanism for data collection and processing, gathering information and knowledge for the territory, which, through the use of various statistical methods and models, ensures decision- formulating public policies for the absorption of territory and space. Four spatial planning is integrated into spatial planning, the first being spatial planning, which has an economic component, urban planning and its social dimension, the third is ecological, and the fourth is related to the preservation of the cultural and historical heritage. In the European context, the ideas presented in a number of documents pertaining to spatial planning and regional development are based on the opportunities for policymaking to contribute to territorial cohesion, integrated urban regeneration and development and the implementation of multi-dimensional territorial management. However, in order to optimally exploit the potential of the territories, it is necessary to implement development strategies that are based on local and regional specificities and needs but also to create specific territorial advantages that have a positive impact on enhancing the competitiveness of the regions in the construction of Europe's regions, which is a real policy for the long-term development of European regions. At European level, the following main emphasis can be drawn on the implementation of spatial development policies, namely, in the first place, a precise regulatory framework that justifies ongoing spatial planning processes. Secondly, the rigid system for the availability of planning documents characterizing the spatial planning of the various hierarchical levels defined as the planning hierarchy, the individual administrative-territorial units, namely the areas, municipalities, towns and smaller settlements. The third emphasis on spatial planning is based on integration and subordination between spatial planning documents, regional development and individual sectoral development strategies as well as national development strategies covering the territory of the whole country. The fourth major focus is on creating a broad involvement of civil society and stakeholders in the process of preparation, implementation and monitoring of public spatial planning and development policies on the territory of the regions and the country.

\section{PARTICULARITIES IN SPATIAL PLANNING IN BULGARIA AND MEMBER STATES OF THE EUROPEAN UNION}

In Bulgaria, the implementation of spatial planning is closely linked to the application of regional development instruments, thus aiming at the creation of an integrated concept based on the application of the strategic approach to spatial planning and spatial development. Spatial planning in the country is based on two normative documents, namely the Law on Regional Development and the Spatial Planning Act, where it is noted that "Spatial Development Planning covers the development and updating of a system of spatial development documents at national and regional level, defining a strategy for integrated spatial development, taking into account territorial potential and principles of balanced sustainable development "[2]. While the Regional Development Act states that "spatial development planning of the territory comprises a system of normative 
documents aimed at simultaneous integration into the European space, development of a balanced polycentric network and integrated urban regeneration and development, territorial connectivity and access to public and private services, sustainable development and preserved natural and cultural heritage, improving the status of specific territories with unfavorable socio-economic, geographic and demographic characteristics, investment promotion, competitiveness and innovation, implementation of territorial integration of border areas and transnational level, making it possible to reduce disaster risk in endangered areas. "[3]. In Bulgaria, the preparation of the Spatial Development Concept was launched in 2011, but covers the period from 2013 to 2025. , while Greece has its strategy already in 2002, Slovenia in 2004, Czech Republic in 2006, and Romania in 2008., which provides opportunities for country experts to explore the experiences of some countries and take advantage of good practices in spatial planning. Despite the possibility to learn from foreign experience in spatial planning in the developed methodological guides, the necessary clarity is not provided for the use of coordination, coordination and integration mechanisms with the available planning documents, but only provide partial guidance to ensure coherence with sectoral policies in the country that shows that our country is lagging behind in implementing spatial planning in comparison with other member states. This fact is complemented by the lack of coordinated efforts to pursue a regional and spatial development policy that unites the scattered efforts between public sector institutions, the private sector and civil society to build and implement spatial planning and development policies across the country. "The long delay in designing and adopting the National Spatial Development Concept, the lack of a vertical and horizontal connection between planning tools, including those for regional development, raises the question of the cost of transition in territorial development and the objective assessment of the current state of planning Bulgaria in the context of the social, demographic, economic and political crisis of recent years. We should not forget two of the main issues that planning must overcome - the possibility of a more intense change in the culture of understanding the territory, respectively of planning, and the related cognitive dimension, in order to overcome and avoid "unsustainable "Legal and technical practices" [4].

Table 1: Directions of Europeanization and Policy Transfer

\begin{tabular}{|c|c|c|}
\hline $\begin{array}{c}\text { Europeanization } \\
\text { direction }\end{array}$ & $\begin{array}{c}\text { Policy Transfer } \\
\text { dimensions }\end{array}$ & General type of Transfer \\
\hline $\begin{array}{c}\text { Vertical: Bottom-up } \\
\text { (Uploading process)/Soft }\end{array}$ & Uploading & $\begin{array}{c}\text { Voluntary } \\
\text { (by consent) Soft Transfer }\end{array}$ \\
\hline $\begin{array}{c}\text { Vertical: Top-down } \\
\text { (Downloading process )/Hard }\end{array}$ & Downloading & $\begin{array}{c}\text { Coercive } \\
\text { Hard Transfer }\end{array}$ \\
\hline $\begin{array}{c}\text { Horizontal } \\
\text { (Cross loading process)/Soft }\end{array}$ & Horizontal & $\begin{array}{c}\text { Unilateral } \\
\text { (intergovernmental learning and sharing) Soft Transfer }\end{array}$ \\
\hline
\end{tabular}

The following table [5] presents the policy transfer, which may be "top-down" or "bottom-up", as well as horizontal or combined. The directions in the process of Europeanization can be identified as soft and hard adaptation mechanisms, i.e. The European Union is working with a mix of "violent" and "voluntary" approaches to Europeanization of policies according to which the political transfer is less often (vertical) but more voluntary (vertical and horizontal). In general, vertical transfer can also be an expression of voluntary admission (voluntary "removal") or voluntary transfer of the European Union - the generated discourse, concepts and principles of spatial planning at 
national (or local) level. Therefore, reporting on the vertical top-transfer transfer, but on the initiative of the local / national actors ("below"), by "overcoming" the conceptual framework for spatial planning by the European Union, documents of advisory nature allow for analysis and discussion in the evolution of internal spatial thinking [5].

The implementation of spatial planning tools, including the use of integrated plans, is conditioned by the existence of political and economic (non) stability in the country, resulting in a process of discrimination against urban areas, resulting in integrated urban plans reconstruction and development three areas of intervention and intervention. In addition, small municipalities and cities are clearly aware of the lack of administrative capacity due to the lack of a culture of planning and the lack of funding for the preparation and implementation of plans at local / regional level.

\section{POLICY ORIENTATIONS ARE TERRITORIAL COHESION AND REGIONAL DEVELOPMENT}

To set up an opportunity to identify successful socio-economic development approaches it is necessary to plan specific guidelines and make recommendations on European policy and related legislation. Significant differences are observed in land-use decision-making processes that result from the application of different models and the construction of specific legal, constitutional and administrative frameworks to outline the trends and consequences of spatial development of the territory as well as to differentiate its management and planning. This necessitates the harmonization of the European and Bulgarian legislation in the sphere of spatial planning and the elaboration of plans and strategies for balanced sustainable development. Regional policy, regional development and spatial planning are linked to a number of concepts, concepts, initiatives such as balanced sustainable development, green infrastructure development, a blue regional economy, the development of integrated management plans, and so on. In general, it can be determined that the European Union's regional policy is an investment policy as it supports the creation of new jobs, aims at improving the competitiveness of regional enterprises, striving to achieve regional economic growth, with considerable efforts to improve the quality of life in the different regions of the European Union and, last but not least, regional policy aims at achieving a sustainable balanced development of regions. It is precisely in pursuit of these objectives that the European Union's investment activity is based on the implementation of the Europe 2020 Strategy [6]. The main focus of the regional development policy of the regions in the European Union is the achievement of harmonious territorial development, which is in fact an essential element in the development of integrated management plans for the regions of the European Union. In this context, integrated management plans are seen as a system of interrelated projects and policies aimed at permanently improving the economic, material, social and environmental situation of a given city or region. As through the integration process, the aim is to achieve the sustainability and efficiency of all activities considered in their interconnection, i.e. the integrated plan should identify the prospective development and relationships between all systems and their elements that affect the quality of the environment and the population in the regions. Integrated Urban Reconstruction and Development Plans are a necessary prerequisite for enhancing the efficiency of absorption of the EU Structural Funds, on the other hand it is intended to attract investment to accelerate regional economic growth while enhancing the planning and development process the urban environment and the creation of smart cities. Thus, the European guidelines for the spatial and urban structure of the countries and the planning regions are 
gradually emerging, which is reflected in the development of national spatial development concepts to ensure the sustainability of the urban network and to build a quality urban environment that meets the needs of the population, which inhabits it.

\section{USE OF THE TARGET INVESTMENT PROGRAM IN SPATIAL PLANNING TO OVERCOME THE ECONOMIC BACKWARDNESS OF THE REGIONS}

Reconsideration and use of the targeted investment program will create an opportunity to overcome the economic backwardness, attract investment and increase employment in the different territorial units in the country. The implementation and implementation of a Targeted Investment Program must be carried out simultaneously with the implementation of the strategic goals set for the stimulation of the socio-economic development of the underdeveloped regions of the country, using the possibilities for absorption of funds from the European Social and Structural Funds. One of the important tasks of the targeted investment program should be to achieve a real impact on the economy of the lagging regions in the long run, to support the development of human capital and, at the same time, to create the conditions for more effective territorial coordination of investment in the regions. For this reason, it is imperative that the targeted investment program includes a package of measures such as reduced tax rates for firms opening new jobs in the underdeveloped region, to be creating the opportunities to subsidize $50 \%$ of the value of interest rates on investment loans, as well as providing the opportunity for the renting of land and buildings in industrial areas/parks/ of enterprises operating on the territory of the underdeveloped region. In order to have a lasting and visible effect, it is vital to adopt such an approach of creating an economically attractive area through targeted state action and by applying a package of business preferences by the local administrative structures, which must be guaranteed for a period last - minimum 10 years.[7]Naturally, significant efforts should be made by state institutions to provide opportunities for qualifications and re-qualification of the population, especially in backward areas, where „unfortunately, the collaboration between the educational institutions and the private sector is far from satisfactory. The appropriate link between theory and practice has not been established yet. Many employers are not satisfied with the practical skills that the graduates have. It is especially important to increase investment in human capital with the state employers, local authorities and regional communities sharing the burden without ruling out individual responsibility. Concrete tools for implementing the policy of continuing vocational training and life-long learning could be: the establishment of sectoral funds for improving the qualification of the employed and setting up individual training accounts $[8]^{\prime \prime}$.

\section{CONCLUSION}

The implementation of European policies and instruments for spatial planning and regional sustainable development help regions and local communities to tackle the socioeconomic problems that exist in them. In addition, spatial planning provides the opportunity to achieve regional economic growth, thus fulfilling the tasks set to achieve the objectives of the European Resource Efficiency Initiative set out in Europe. Additionally, public awareness on the protection and management of spatial development should be further enhanced by working in a coordinated and joint European Union context. The results show that there are countries in the various regions of the world who demonstrate good practices with regard to the use of information and communication 
technologies to provide services and to create citizens' ownership of the decision-making processes. An important trend in recent years has been the development of people-driven services, which simultaneously reflect the needs of people and have been suggested by them. On the other hand, disparities between countries also lie in the lack of access to technology, the high poverty and disadvantages of significant population groups in individual countries that we can relate to preventing people from benefiting from the benefits of information and communication technologies and management [9]. In our country, attempts have been made to curb the demographic decline of the nation, as the main strategic objective is to slow the pace of reduction in the number of the population with a view to achieving a trend of stabilization in the long term and of ensuring high quality of human capital [10] Particular attention should be paid to the demographic factor in the shaping of social and economic development programs and the implementation of regional economic and social policies. [11]

\section{REFERENCES}

[1] The EU compendium of spatial planning systems and policies, 1997, p. 36-37, available to https://publications.europa.eu/en/publication-detail/-/publication/059fcedf-d453-4d0d-af366 f7126698556 on 10.01.2019.

[2] Spatial Development Act, Art. 100, 5 July 2016 available at https://lex.bg/laws/ldoc/2135163904, on 10/01/2019

[3] Regional Development Act, Art. 3, para. 1, 23 February 2016 available to https://www.mrrb.bg/bg/zakon-za-regionalnoto-razvitie/ on 10.01.2019

[4] Simeonova, V., Europeanization and Spatial Planning in the Balkan Context: Problems and Challenges for Bulgaria, Journal Geopolitics available to https://geopolitica.eu/137-broi-32015/2248-2015-07-20-16-17-18 on 10.01.2019.

[5] Simeonova, V., Transfer of European Spatial Planning Discourse in Bulgaria: National Concept for Spatial Development, available to https://www.e-acadjournal.org/pdf/article-17-36.pdf on 10.01.2019.

[6] European Commission, Regional Policy, available to http://ec.europa.eu/regional_policy/index_bg.cfm on 10.01.2019

[7] Ivanov, M., Peculiarities in the socio-economic development of the regions in Bulgaria , Annual of the University of mining and geology „St. Ivan Rilski“, Vol. 60, 2017, p.35-39

[8] Naydenov Kl., Education and employment in South East Europe, 13th International scientific conference „The teacher of the future“, Budva, Montenegro, 25-28 may 2017

[9] Naydenov, Kl., Regional differences and trends in e-governance, IX-th International scientific conference „E-governance and E-communications“, 2017, p. 45-52, ISSN 2534-8523

[10] Naydenov, K1., „The demographic deficit in the economic development of the Republic of Bulgaria - consequences and decisions“, SGEM 2017, Book 1 Modern Science Volume IV, p. 785 - 792, ISBN 978-619-7408-16-4

[11] Naydenov, Kl., Influence of the demographic factor on the regional social and economic development", SGEM 2017, Volume I, p.363 - 369,ISBN 978-619-7408-23-2 